\title{
Teaching Arabic to Spanish Speakers: Teacher's Opinion-Perspective
}

\author{
MOHAMAD WORJIN \\ JAVIER VILLORIA \\ University of Granada
}

Received: 01 June 2017 / Accepted: 10 November 2017

ISSN: $1697-7467$

\begin{abstract}
This paper is a qualitative study performed by 10 professors of Arabic to Spanish speakers in Spain, specifically in the region of Andalusia, Granada. The aim of this study is to evaluate the status of teaching/learning Arabic as a foreign language contingent on the reality of the teacher's training, their capacity to self-evaluate, evolution, and their vision in this area of investigation. Through the interviews conducted, the study attempts to shed light on the teacher's interest, their contact with the language and its ambit. The important conclusion attained is the lack of resources for the professor of Arabic coming from other fields of investigation.
\end{abstract}

Keywords: Arabic to non-native speakers, Arabic language in Spain, Professor of Arabic to non-native.

La enseñanza de la lengua árabe para hispanohablantes: Opiniones y perspectivas de profesores

RESUMEN: Este trabajo es un estudio cualitativo aplicado a 10 profesores de árabe a hispanohablantes específicamente en España, Andalucía, Granada. El objetivo es evaluar el estatus de la enseñanza / aprendizaje del árabe como lengua extranjera de acuerdo con la realidad de la formación del docente, su capacidad de autoevaluación, evolución y su visión en este campo de investigación. El estudio trata a través de una entrevista de sacar a la luz el interés del profesor y su contacto con el lenguaje y su ámbito. La conclusión más importante es la falta de recursos del profesor de árabe que en muchas ocasiones vienen de otros áreas o especialidades académicas.

Palabras claves: árabe para hablantes no nativos, lengua árabe en España, Profesor de árabe para hablantes no nativos.

\section{INTRODUCTION}

Knowledge of a problem is not only an essential part of the solution, but it is the first step towards its fulfilment. The primary objective is to reveal the teacher's role in the process of teaching and learning Arabic. There should also be an awareness of the teacher's issues with their training, as the teacher must follow the new trends and circumstances in the European context of education (Romero-Cerezo, Villoria and Hidalgo, 2011). Other difficulties cannot refer to the personality of the teacher but should fall within problems with the curriculum and a lack of educational resources. 
In this research, which consists of interviews with 10 Arabic teachers to non-native speakers in Spain ${ }^{1}$, (in the region of Andalusia), we try to get closer to the reality of the teaching of Arabic as a foreign language (TAFL) in Spain.

The region of Andalusia, particularly Granada, has been selected to carry out this study for many factors, such as student's willingness to learn Arabic, as it is a language of interest, the large Arab population which is further motivation to learn the language, the historical heritage related to the Arabic language and its civilisation and finally the geographical proximity to the Arab world. All these factors constituted a huge incentive to learn the Arabic language and that is why many centres of TAFL, such as the university and official schools of languages, exist.

The paper intends to present TAFL in Spain from a historical perspective. This helps identify how the teaching developed in this area and how the results of this development were manifested.

\section{Teaching Arabic in Spain}

First, we need to look at the history of Arabic in Spain, including language teaching centres, methodologies, and some of the social, political and economic circumstances surrounding the learning and teaching process of Arabic.

As mentioned above, due to the historical and geographical proximity to the Arab world, and its close relationship with Arab heritage, (which is an important part of its richer historical stages and civilisation), Arabic studies in Spain have been ascribed to a clear purpose; namely, having access to the old Arabic texts, understanding them, reproducing or publishing them, so the principal charge of the Arabic studies in Spain was Al-Andalus and everything related to it, this job needs to a lot of work, time and hands. This goal still has its effects on the curricular resources, teaching methods and teacher training in general, as Corriente (2010:12) say: "our Arabic scholars have for decades almost thoroughly ignored the linguistic and dialectological aspects of their main concern, the Arabic language". All this can be seen, for example, in some methods that were prevalent in the first half of the last century such as the method of Miguel Asín Palacios in his work, "poor bock" as Corriente call it: Crestomatia de árabe literal con glosario y elementos de gramática (Paradela, 2009: 30), that had remained in use until the "Grammar-translation method" was established and appeared.

This was followed by the writings of Federico Corriente in the second half of the last century (Hamparzoumian, 1997: 27). It seems really that the history of the Arabic studies and their elaboration of manuals "before the last quarter of the $20^{\text {th }}$ century was symptomatically very scarce, it being ineluctable to undertake a diagnosis and correction of the situation or, at least, trying to do it" Corriente (2010: 12)

Traveling to, and living in the Arab world was an important factor in Arabic studies in Spain. Good evidence can be found in Martínez Montávez's academic work at the University of Autónoma de Madrid, and his translations of Arabic contemporary poetry (Roser, 2015:

\footnotetext{
${ }^{1}$ It does not mean that all of students are no natives, because there are native students.
} 
54-55). Aguilar states that Arabism was rooted in the traditional trend of university teaching in General (Aguilar, 2011: 82). Finally, the Escuela Oficial de Idiomas was established in Spain. It was a unique phenomenon in Europe, and an option to learn Arabic language based on the communicative approach. This prompted some schools to introduce regional dialects in the teaching and focus on them as the first tool of linguistic communication.

This latest trend resulted in the setup of conferences, seminars and workshops which benefited from-experiments in this area, particularly by some researchers at the American universities. Professor Munther Younes was invited to Murcia in (2014) to speak on this topic based on his experience in the integrational approach in TAFL. Lately Arabic teaching centres along with their methods have increased. In addition, the Faculty of Arts focuses on history, literature and politics along with the Arabic language.

There are Faculties of Translation and Interpretation that are interested in translating into/from Arabic, and all such services require a good level of knowledge of the Arabic language. Nine Spanish universities impart Arabic language (Assaf, 2014: 8). There are also the Escuela de Traductores de Toledo, Escuelas Oficiales de Idiomas, Casa Árabe in Madrid and Cordoba where Arabic language courses are offered. Moreover, such courses are also offered by Islamic centres and various municipal centres where they are aimed at both children and adults.

The centres of TAFL and the teaching methods have increased in a notable way, reasons for this including the size of the Arab community in Spain, the presence of the Arab world on the political arena and the possibility of work in some Arab countries.

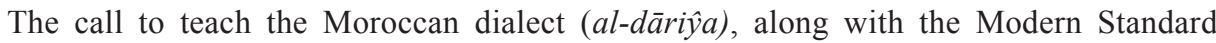
Arabic (MSA), is a modern trend that takes into account the large Moroccan community, which reached (non-Spanish nationals) 717.992² inhabitants in December 2014.

\section{Goals of THe STUdy}

The main objective of this research is to develop a better understanding of the context of TAFL in Spain, which is surrounded by many question marks. After four years of study and contact with the Arabic language, students come out unable to speak or handle simple dialogs in the Arabic language (Valera \& Aguilar, 2013: 198). The goals are thus as follows:

- To determine the challenges and problems facing the teacher of Arabic working with non-native speakers.

- To establish the teacher's opinion of Arabic in the process of his/her teaching, training, and the relationship between their training in TAFL according to their academic background.

- To display the role of the teacher of the Arabic language, and the effect of their attitude towards Arabic culture in the teaching process.

\footnotetext{
${ }^{2}$ http://www.ine.es/jaxi/tabla.do [27/04/2015]
} 


\section{Methodology}

This research has followed a qualitative methodology, in other words descriptions of what occurs based on interpretations of what is observed (Johnson and Christensen, 2014: 418). Direct and structured interviews with teachers and professors have been carried out, according to (Lichtman, 2006: 118) you can do that, structured interview, where the interview and the question is the same for all the participants. The interviews are basically a review of the role of the teacher, his/her training, their linguistic level, other aspects related of their personality, and any information that make easer understand the collected data (Lodico, Spaulding and Voegtle, 2010: 157). The interviews are conducted in Arabic and the teachers have paid great attention to avoid responding with simple answers: such as "yes" or "no.

The results are no more than a description of the current status of TAFL in Spain, therefore.

\subsection{Participants}

The participants, in total, were 10 Arabic language teachers all of whom have different specialities.

Each interview took 30 to 60 minutes to complete.

Table 1: Data description.

\begin{tabular}{|l|c|c|c|c|c|}
\hline & Non-native & Native & Female & Male & All \\
\hline $\begin{array}{l}\text { Faculty of } \\
\text { Arts }\end{array}$ & 5 & 1 & 2 & 4 & 6 \\
\hline $\begin{array}{l}\text { Faculty of } \\
\text { Translation } \\
\text { and } \\
\text { Interpreting }\end{array}$ & 1 & 1 & 1 & 1 & 2 \\
\hline $\begin{array}{l}\text { Escuela } \\
\text { Oficial de } \\
\text { Idiomas }\end{array}$ & 1 & 1 & & 1 & 1 \\
\hline $\begin{array}{l}\text { Euro-Arab } \\
\text { Foundation }\end{array}$ & & & & 1 & 1 \\
\hline
\end{tabular}

\subsection{Data Collection and Analysis}

The data was collected through a personal interview with the teachers. It included 10 questions of which the interviewee had no preconceived notion. The interviews were distributed on five basic pillars, in the following sequence:

- Training of the teacher. 
- Identity of the language teacher (native vs. non-native teacher).

- Attitude towards the Arab culture.

- Contact with the language.

- Other factors and motives to teach and learn Arabic.

According to (Norton, 2009: 116) Qualitative analysis is better always when:

- Little is known around the research, and the study try to discover new facts.

- To understand different perspectives of persons.

- Depth information is required.

- More sources are already obtainable.

\subsubsection{Training of the teacher}

Training of teacher is very important because as Gommez Pérez say: "uma grande parte do quê de um ensino depende do como ele é transmitido" (Amado, 2014: 58). Only one of the interviewees $(10 \%)$ recognised having been trained and prepared in the field of TAFL, in spite of the fact that this training does not exceed a month in Dar Loughat in Morocco (Tetouan), we can have comparison with Spanish teacher's training in (Álvarez-Bernárdez y Monereo, 2016).

Some teachers went on to explain their linguistic training, while others merely answered negatively to any teacher training. It should be noted here that the teachers have talked about classic training in the Arabic language, which is preparation of grammatical abilities. To justify this lack of methodological training, one of the participants added that the reality is that teacher training is not taken into account in the competition to attain a position at the institution he works for (the university).

The proximity of the original academic/research background of the teachers to TAFL was also examined. According to the responses provided, none of them had the exact speciality, with most of them coming from other related fields such as history or literature or even politics of the Arab world. The only case of a teacher training background, as previously mentioned, was a general Arabic language and literature professor.

\subsubsection{Identity of the language teacher (native vs. non-native teacher)}

The second issue that we try to raise is concerned with which option is preferable, a native or non-native language teacher, which is a frequent matter in the books and theories of foreign language teaching. Furthermore, as the sample case involved teachers who were native speakers, this provided a great chance of seeing the subject from different perspectives (Karaman, Ökten and V. Tochon, 2012; Pavón, 2003). Thus, the opinions generated on the native language teachers were quite divergent views, with some feeling that native Arabic language teachers need to be more organised and committed to the curricular program.

Some argue that mastering the language here is not the first criterion in the selection of the teacher or the professor because they did not go through a phase of conscious language learning; and as such, native teachers do not know the difficulty that non-native teachers encounter. While other prefer the native language teachers in upper levels of TAFL, who 
have enough linguistic competence. However, this group of individuals would also rather put the teaching of dialects at the hands of non-native teachers. Some of those interviewed did not place much relevance to the issue, provided that the teacher had their own way and method of teaching (Medgyes, 2001: 440).

The native teacher insists on the importance of the two kinds of teachers, because in their opinion, the non-native teacher can attain the native's level in oral competence with great difficulty. While, they envisage that the native speaker generally and with respect to acquisition of the language, did not go through the same way of conscious learning and did not face learning difficulties in the same way as the non-native speaker.

\subsubsection{Attitude towards the Arab culture}

Concerning the teacher's attitude towards the Arabic culture and the influence of this on their teaching, all of teachers were in agreement that the teaching of the language should include cultural elements. While others reported that the teaching of the language, regardless of this, only positively affected their attitude.

The majority claimed that the more knowledge a teacher had of the culture, then the better they should be at language teaching because language learning involves learning contexts and customs that accompany linguistic use. "Language is the key to log into the culture of the people" citing some of the professors.

Living in an Arab country was another point during these interviews, and it seems that everyone had visited an Arab country and lived there for a time, anywhere from a few months to years. The countries most represented here were: Morocco, Tunisia, Egypt, Lebanon and Syria. They all agree on the need to travel and live in the Arab world. A teacher without this experience cannot have a clear image of the Arab world, which in turn, is provided to the students. They, the students, can travel, taking advantage of exchanges programs to these countries as well, where they can deal with the language on a daily basis in the social and cultural contexts. This experience is indispensable, and should be compulsory for any teacher of Arabic.

\subsubsection{Contact with the language}

The next questions are related on whether they have continuous contact with the language. Unfortunately, according to the information obtained in these interviews, the teachers are not exposed to constant contact with Arabic, and in most cases it is limited to watching movies, or some simple family conversations, or conversations with the students in the department. For some of the native professors, the Arabic language is only limited to reading and thinking. This analysis, focussed in Spain, shows a lack of conversational workshops, linguistic exchanges, and this observation is supported by most teachers speaking in Spanish in response to the questions in these interviews.

\subsubsection{Other factors and motives to teach and learn Arabic}

Finally we asked for other factors and motives to teach and learn Arabic. Most of the motives are repeated and all relate to a love for the Arabic language and culture. Here we 
present some of the answers:

- Distance and differences between Arabic and other European languages.

- Loving Arabic as a language, an essential component of Spanish history.

- Loving Arabic language and people that speak it.

- Arabic is beautiful, and it can open doors for the study of literature and history.

- I think I love Arabic culture and civilisation, more recently for the heavy presence of the Arab world in the political arena and our geographic proximity to it.

- The Arab world elevates my curiosity.

- I love the Arabic language.

\section{Results}

The first result, which corresponds with the first goal of this study, is that no one has received enough practice in the field of TAFL. This is certainly eye-opening. As such, the challenge falls on how to prepare future Arabic teachers for this role through appropriate training and accordingly to result in good students. This problem can be resolved by a form of collaboration between the education programs and the faculty of arts.

The original areas of research of teachers, far or close to the teaching of language, centred on the historical and literary studies of Arab heritage, or even on the policies or Arab society, this is a principal character of the Arabic studies in Spain but the tool for all these studies is the language. The language suffers and other areas can be seen to be affected.

There is a clear lack of native teachers, something that probably carries negative connotations when talking about the quality of teaching, and is probably linked to the education system and how teachers are chosen.

The prevailing attitude towards Arabic culture is an overly positive one, which involves a love and appreciation for Arabic civilisation and culture.

All teachers have had the opportunity to visit an Arab country. Everyone managed to live even for a short time and experienced aspects of social life. This is what encourages the transfer of the true image of the present Arab world which is not offered in the media.

The language level depends on the teacher's training and interest; despite the lack of time during the academic year and the necessity to carry out all the academic tasks.

There are many motivations to learn Arabic in Spain, which reflects the love and appreciation of it. This is a love that probably does not exist in the learning of other foreign languages where learning and studying have a lot of goals related to curriculum vitae and looking for jobs.

\section{REFERENCES}

Aguilar, V. (2011). "Enseñanza del árabe en España", in Dialogos, available from: www.academia. edu/6710670/Enseñanza_del_árabe_en_España, accessed 24 april, 2015.

Aguilar, V. and Valera, A. (2013). "Cómo enseñamos árabe? La voz de los alumnos", in Revista de estudios internacionales mediterráneo 15, 179- 204. 
Álvarez-Bernárdez, P.R. and Monereo, C. (2016). "Formación del profesorado de ELE y evaluación. Construcción de una guía para autentificar pruebas de español lengua extranjera", in Porta Linguarum, 25, 163-177.

Amado, J. (2014). "A formação em Investigação Qualitativa: Notas para a Construção de um Programa", in Costa, A.P., Neri de Souza, F. and Neri de Souza D. (eds.), Investigação Qualitativa: inovação, dilemas e desafios. Aveiro: Ludomedia, 39- 67.

Assaf, T. (2014). Al-taḥaddiyāt allatī yuāŷihuhā al-țullāb al-isbān fị țarīqihim li-ta allum al-'arabiyya lil-nāțiqīn bi-gayrihā, in al-mu'tamar al-dawlì al-țālit lil-luga al- 'arabiyya, available from: http://www.alarabiahconference.org/modules/speaker/view4.php?id=3 accessed 04 noviembre 2015.

Corriente, F. (2010). "Arabic dialects before and after Classical Arabic", in Monferrer-Sala, J.P. and Al Jallad, N. (eds.), The Arabic Language Across the Ages. Wiesbaden: Reichert, 11-18.

Hamparzoumian, A. (1997). "Elegir un texto", in Algarabia 5, 25- 32.

Johnson, B. and Christensen, L. (2014). Educational Research Quantitative, Qualitative and Mixed Approaches, $5^{\text {th }}$ ed. Thousand Oaks: SAGE Publication.

Karaman, C., Ökten C., and Tochon, F.V. (2012). "Learning the Deep Approach: Language Teachers' Voices", in Porta Linguarum 18, 79-95, available from: http://www.ugr.es/local/ portalin accessed: 7 November 2015.

Lichtman, M. (2006). Qualitative Research in Education, A user's guide. Thousand Oaks: SAGE Publications.

Lodico, M., Spaulding, D. and Voegtle, K. (2010). Methods in Educational Research from Theory to Practice, 2nd ed. San Francisco: Jossey-Bass.

Medgyes, P. (2001). "When the Teacher Is a Non-native Speaker", in Celce-Murcia, M. (ed.), Teaching English as a Second or Foreign Languge. Boston: Heinle \& Heinle, 428-443.

Norton, L. (2009). Action Research in Teaching \& learning. Oxon: Routledge.

Paradela, N. (2010). "La gramática del árabe clásico en España durante el siglo XX: un balance crítico", in Aguilar, V., Pérez Cañada, L.M. and Santillán Grimm, P. (eds.), Arabele 2009, enseñanza y aprendizaje de la lengua árabe. Murcia: UM, 29-45.

Pavón, V. (2003). "El papel de los profesores no nativos ante la enseñanza de la pronunciación", in G. Luque, A. Bueno and G. Tejada (eds.). Las lenguas en un mundo global / Languages in a global world. Jaén: Universidad de Jaén, 237- 249.

Romero-Cerezo, C., Villoria, J. and Hidalgo, E. (2011). "Teacher trainees and social educators'choices of methodological strategies in their training process". in: Procedia Social and Behavioral Sciences 15, 297-298.

Roser, N. (2015). "Al-luga al-arabiyya fĩ isbānya" in Maoulainine, M. (ed.), Al-luga al-arabiyya fì isbānya, 35-66. 


\section{Appendix}

\section{Interview questions}

- Have you received sufficient training in the field of teaching Arabic to non-Arabic speakers?

- Is your academic background near to the level of TAFL or far from it?

- What is your opinion, as a teacher of foreign Arabic language, on the native teacher of Arabic language?

- Does the attitude of the teacher towards the Arab culture affect the teaching of the language?

- Have you ever been to an Arab country?

- To what extent does living in an Arab country affect the training and teaching of the teacher?

- Do you practice speaking in Arabic habitually?

- With whom do you practice the Arabic language?

- Do you feel that the level of your language decreases with time or advances and what are the reasons for this in your opinion?

- What are your motivation reasons for teaching Arabic, other than being a teacher? 